\title{
Particulate organic matter fluxes in a Tuamotu atoll lagoon (French Polynesia)
}

\author{
Loïc Charpy, Claude J. Charpy-Roubaud
}

ORSTOM, PO Box 529, Papeete, French Polynesia

\begin{abstract}
The standing stock and chemical composition of suspended particles $(<35 \mu \mathrm{m})$ were monitored in the lagoon of Tikehau Atoll from 1983 to 1987 and in surrounding oceanic waters (upper $250 \mathrm{~m}$ ) during 4 cruises. Trapping rate of particulate material was measured between 1986 and 1987 and net export of particulate organic matter (POM) was roughly estimated using monthly average lagoon POM concentration and monthly average flow of water measured in the passage and the reef-flat spillways. Results showed that deep chlorophyll maxima in oceanic waters could reach $0.24 \mathrm{mg} \mathrm{m}^{-3}$ and were observed between 100 and $200 \mathrm{~m}$ even when ATP, POC, PON and POP concentrations were higher in the upper $100 \mathrm{~m}$. POM concentration was homogeneous in the lagoon but varied considerably with time especially following 2 hurricanes in 1983. POM concentration was 30 to $40 \%$ higher in samples taken close to the bottom than in the water column. An oceanic station near the atoll was strongly influenced by the lagoonal discharge but POC export from the lagoon to the ocean represents only $6 \%$ of phytoplankton production. The POM content of Tikehau lagoon lies within the range recorded for coral reef areas and is made up of suspended particles $50 \%$ of which are smaller than $5 \mu \mathrm{m}$. Their sedimentation ( $350 \mathrm{mg} \mathrm{C} \mathrm{m} \mathrm{m}^{-2} \mathrm{~d}^{-1}$ ) represents $80 \%$ of phytoplankton production.
\end{abstract}

\section{INTRODUCTION}

Of the 84 atolls of French Polynesia, 76 constitute the Archipelago of Tuamotu. The lagoons of the archipelago play an important role in the French Polynesian economy: cultured pearls from pearl oyster aquacultures in Tuamotu atoll lagoons are French Polynesia's major export; in addition, lagoon fisheries supply a major part of the local fish requirement.

An estimate of lagoonal productivity is necessary to assess the lagoons' potential for exploitation. Such estimates are difficult to make due to the diversity of lagoonal primary producers: phytoplankton, macrophytes, sand microphytes, and epilitic and symbiotic microphytes. Moreover, the flux of detritus particles flowing from the coral reefs into the lagoon may also be important to lagoon organisms (Gerber \& Marshall 1982). The particulate organic matter (POM) content of the water column seems to be a good index of lagoon productivity (Charpy 1985). However, so far, only one study has been published on the organic matter found in Polynesian lagoonal waters (Charpy 1985). Other lagoonal studies dealt with phytoplankton productivity (Sournia \& Ricard 1975, 1976, Delesalle 1985, CharpyRoubaud et al. 1989) or phytobenthos productivity (Sournia 1976, Charpy-Roubaud 1988).
Measurements of organic material deposition are very important. Nutrient requirements for lagoonal production may be met through recycling of autochthonous material in the sediments. One of the principal factors which governs rates of nutrient regeneration from sediments is the amount of organic matter incorporated into those sediments from the water above (Koop \& Larkum 1987).

Polynesian atolls may be divided into open and closed atolls. The export rate of organic material from an open atoll may be considered as the net production of the atoll. Comparisons between the export of POM and other lagoonal fluxes allows an estimation of the relative importance of lagoonal fluxes and the influence of atoll morphology on lagoonal communities. We studied the abundance, rate of deposition on the lagoon floor and export rate of POM in an open atoll of the Tuamotu archipelago from 1983 to 1987

\section{STUDY SITE}

The atoll chosen for study was Tikehau, situated in the northwest of the Tuamotu Archipelago; its geomorphological characteristics make it suitable model of a mid-size open atoll. 


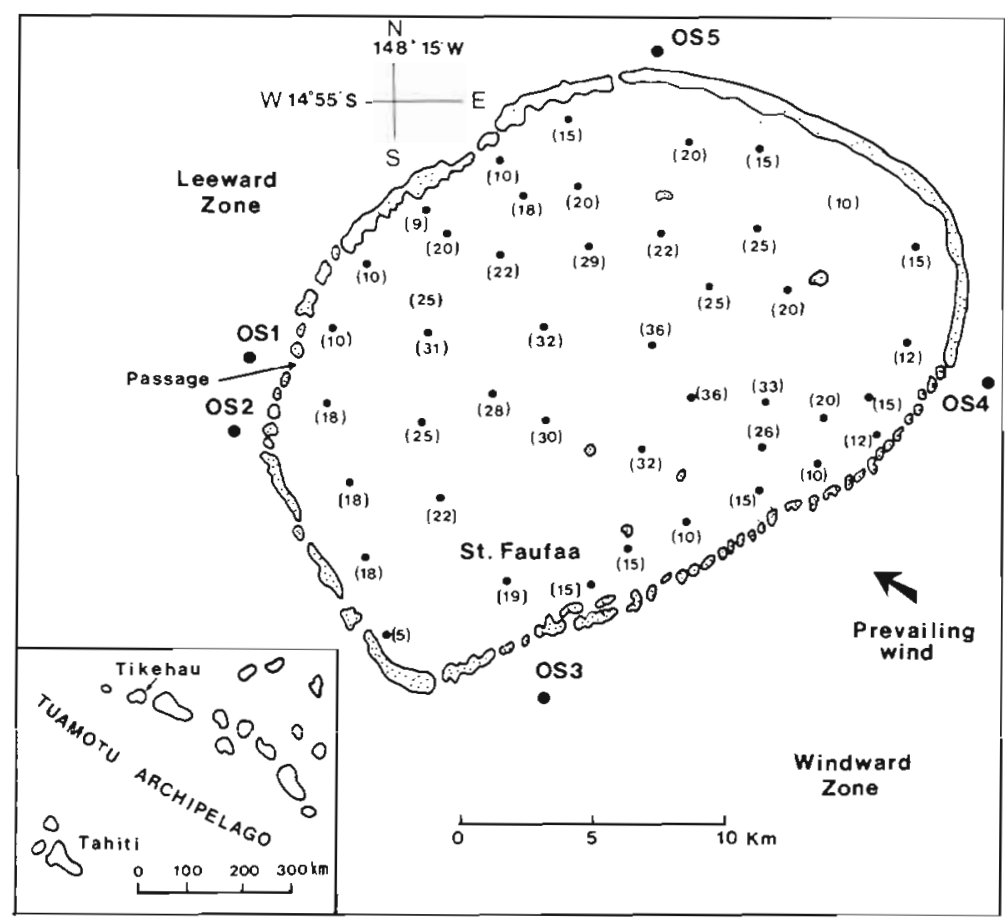

Fig. 1. Location of sampling stations. Ocean Stns OS2 to OS5 were $2 \mathrm{~km}$ from Tikehau Atoll and Stn OS1 was located $2 \mathrm{~km}$ from the passage between lagoon and ocean. Stn Faufaa served as lagoon reference station.

Values in parentheses show depths in metres

Tikehau is almost circular (Fig. 1): its widest diameter (NE-SW axis) is nearly $28 \mathrm{~km}$. The reef rim is ca $78 \mathrm{~km}$ long and has a width - taken between the algal ridge and the edge of the lagoon - ranging from less than 300 to $1300 \mathrm{~m}$ (Intes 1984). The lagoon has an area of $400 \mathrm{~km}^{2}$; of this $91 \%$ has a depth greater than $15 \mathrm{~m}$, while the average depth is $25 \mathrm{~m}$ (Lenhardt 1987). The $25 \mathrm{~km}^{2}$ of islands are intersected by reef-flat spillways which link the lagoon and the ocean; one of these forms a $200 \mathrm{~m}$ wide and $4 \mathrm{~m}$ deep passage at the western end. Except in the passage, currents in spillways generally flow into the lagoon at low speed. The average outward flow in the passage is $700 \mathrm{~m}^{3} \mathrm{~s}^{-1}$, therefore a simple average replacement time for waters in the lagoon is $176 \mathrm{~d}$ (Lenhardt 1988).

Irradiance is high and $17 \%$ of the light energy measured at the surface reaches $25 \mathrm{~m}$ (average depth) (Charpy \& Charpy-Roubaud 1990).

Surrounding surface oceanic waters are enriched in nitrogen and phosphorus, probably by vertical turbulent mixing; except for $\mathrm{NH}_{4}$, mineral nutrient concentrations were lower inside the lagoon than outside (Charpy-Roubaud et al. 1990).

Phytoplankton biomass was low: $0.18 \mathrm{mg} \mathrm{chl} \mathrm{a} \mathrm{m}^{-3}$, dominated by picoplankton; microscopic observations performed during the southern summer showed a high quantity of cyanobacteria (Blanchot et al. 1989). Phyto- plankton average production (integrated up to $25 \mathrm{~m}$ ) was $0.44 \mathrm{~g} \mathrm{C} \mathrm{m}^{-2} \mathrm{~d}^{-1}$ (Charpy-Roubaud et al. 1989).

The zooplankton populations were characterized by successive blooms of copepods, larvaceans, pteropods and salps (Le Borgne et al. 1989). Animals > $200 \mu \mathrm{m}$ comprised $50 \%$ of the total biomass of all organisms from 35 to $2000 \mu \mathrm{m}$. Zooplankton production equalled $34 \%$ of phytoplankton production and its inorganic excretion was respectively 32 and $18 \%$ of phytoplankton nitrogen and phosphorus requirements (Le Borgne et al. 1989).

The lagoon bottom is formed of a fine to very fine calcareous sand. Extensive areas are covered with brown Cyanophyceae. In places, the lagoon bottom is colonised by Halophila seagrass beds. Macroalgae are very sparse. Average sand primary production was estimated to $0.25 \mathrm{~g} \mathrm{C} \mathrm{m}^{-2} \mathrm{~d}^{-1}$ (Charpy-Roubaud 1988).

The upper zone ( 0 to $2 \mathrm{~m}$ ) of pinnacles is colonised by algae (Halimeda, Pocockiella, Caulerpa, Liagora ceranoides, algal turfs). The windward zone is mainly colonised by large colonies of Porites lobata and Millepora platyphylla and the leeward zone by Acropora variabilis, $A$. hyacinthus and $A$. hemprichii. In the mid zone (2 to $6 \mathrm{~m}$ ), algae (Halimeda, Caulerpa) compete with corals (Montipora, Astropora, Psammocora, Porites, Platygyra, Pavona) for sites. The lower zone (6 to $15 \mathrm{~m}$ ) is occupied by coral patches of Montipora verru- 
cosa, Stylocoeniella, Platygyra daedalea and bushes of Acropora formosa, Stylophora pistillata and Favia favus, growing on a detrital or sandy gentle slope (Faure \& Laboute 1984, Harmelin-Vivien 1985).

\section{MATERIAL AND METHODS}

Station location and sampling strategy.

Ocean: Oceanic waters surrounding the atoll were studied during 4 cruises between 1983 and 1985; the sampling strategy is summarized in Table 1 . The 4 stations sampled (OS2 to OS5) are located at $2 \mathrm{~km}$ from the reef rim. Samples were taken using 1.7 l Niskin bottles.

Lagoon: Eleven surveys were carried out in the lagoon (Table 2); water was sampled from $10 \mathrm{~m}$ depth at 46 stations and in addition at $1 \mathrm{~m}$ above the bottom using $5 \mathrm{l}$ Niskin bottles. For each lagoon survey, a station (OS1), located $2 \mathrm{~km}$ seawards of the passage from the lagoon to the open ocean, was chosen as a reference for the neighbouring oceanic waters. Pigments and particulate organic carbon and nitrogen (POC and PON) concentrations were also determined in weekly samples collected at the lagoon reference station (Faufaa, $19 \mathrm{~m}$ depth) between July 1985 and February 1987

Chemical analyses of seston. Seawater samples were first prefiltered through a polyamide screen with $35 \mu \mathrm{m}$ mesh (data on suspended particles larger than $35 \mu \mathrm{m}$ are presented in another paper: Blanchot et al. 1989). Then, (1) 100 to $300 \mathrm{ml}$ were filtered through a Whatman GF/F filter for pigment analysis; (2) 500 to $1000 \mathrm{ml}$ were filtered through a $\mathrm{GF} / \mathrm{F}$ processed filter (precombusted for $4 \mathrm{~h}$ at $450^{\circ} \mathrm{C}$ and precleaned with 1 $\mathrm{N} \mathrm{HCl)}$ for POC, PON and particulate organic phosphorus (POP) analysis and (3) 250 to $500 \mathrm{ml}$ were filtered through a Millipore $0.45 \mu \mathrm{m}$ filter for ATP analysis.

Concentrations of chlorophyll a (chl a) and phaeophytin a (phaeo a) were determined by fluorescence (Yentsch \& Menzel 1963) using a Turner 111 fluorometer.

POC and PON concentrations were determined after rinsing the filter with $20 \mathrm{ml}$ of $\mathrm{HCl}(0.1 \mathrm{~N})$ with a $185-\mathrm{B}$ Hewlett-Packard CHN analyzer (Gordon \& Sutcliffe 1973); a combustion temperature of $720^{\circ} \mathrm{C}$ was chosen to reduce carbonate dissociation (Telek \& Marshall 1974).

POP was oxidized with persulfate at $110^{\circ} \mathrm{C}$ for $1.5 \mathrm{~h}$ (Menzel \& Corwin 1965) and phosphate concentrations subsequently analysed by spectrophotometry (Strickland \& Parsons 1972).

ATP extractions were performed immediately in $5 \mathrm{ml}$ of boiling Tris $(0.02 \mathrm{M}, \mathrm{pH}=7.85)$; ATP extracts were

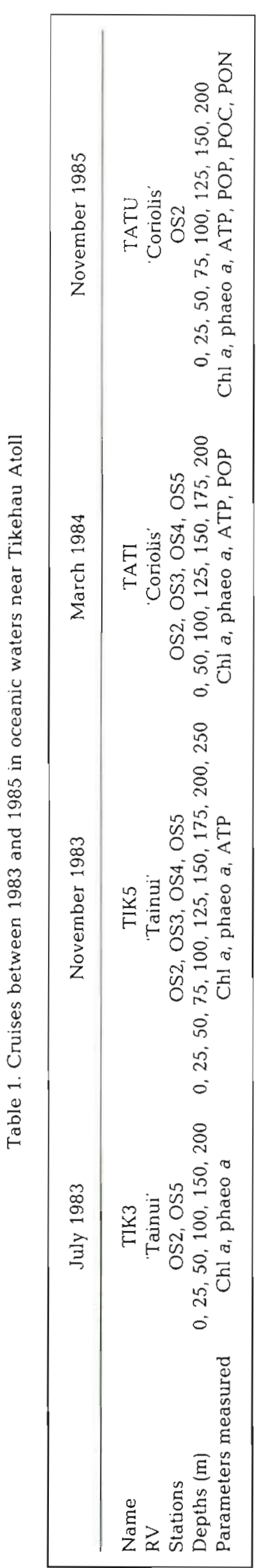


Table 2. Date and number of stations sampled (n) during 11 surveys in the lagoon of Tikehau Atoll

\begin{tabular}{|c|c|c|c|c|c|c|c|c|c|c|c|}
\hline \multirow{3}{*}{$\begin{array}{l}\text { Month } \\
n\end{array}$} & \multicolumn{4}{|c|}{1983} & \multicolumn{2}{|c|}{1984} & \multicolumn{5}{|c|}{1985} \\
\hline & Mar & Jul & Sep & Dec & Feb & Nov & Jan & Mar & Apr & Jul & Aug \\
\hline & 21 & 14 & 22 & 17 & 9 & 10 & 7 & 7 & 7 & 7 & 7 \\
\hline
\end{tabular}

frozen at $-20^{\circ} \mathrm{C}$ until analysis in the Tahiti laboratory. ATP concentrations were measured using the method described by Holm-Hansen \& Booth (1966), with a LKB Luminometer and Luciferine-Luciferase preparations from Sigma (FLE 50).

Trapping rate $(T R)$. Fourteen measurements of trapping rate of particulate matter were performed between January 1986 and May 1987, at the Faufaa station. The sediment trap used in this study consisted of a 8 l PVC plastic jar $(16 \times 40 \mathrm{~cm})$. The ratio of height to width of the jar was 2.5:1 as recommended by Gardner (1980). No poisoning was done, so as to permit measurements of ATP concentration inside the trap. The jar was mounted $15 \mathrm{~m}$ below the surface $14 \mathrm{~m}$ above the bottom) on an anchored nylon rope, and supported by a subsurface float $2 \mathrm{~m}$ below the surface. Material was collected for 6 to $20 \mathrm{~h}$. Seston was resuspended by magnetic stirring and split into 8 aliquots of $500 \mathrm{ml}$ and 2 of $200 \mathrm{ml}$. POC, PON, POP, ATP analysis and weight measurements were made in duplicate

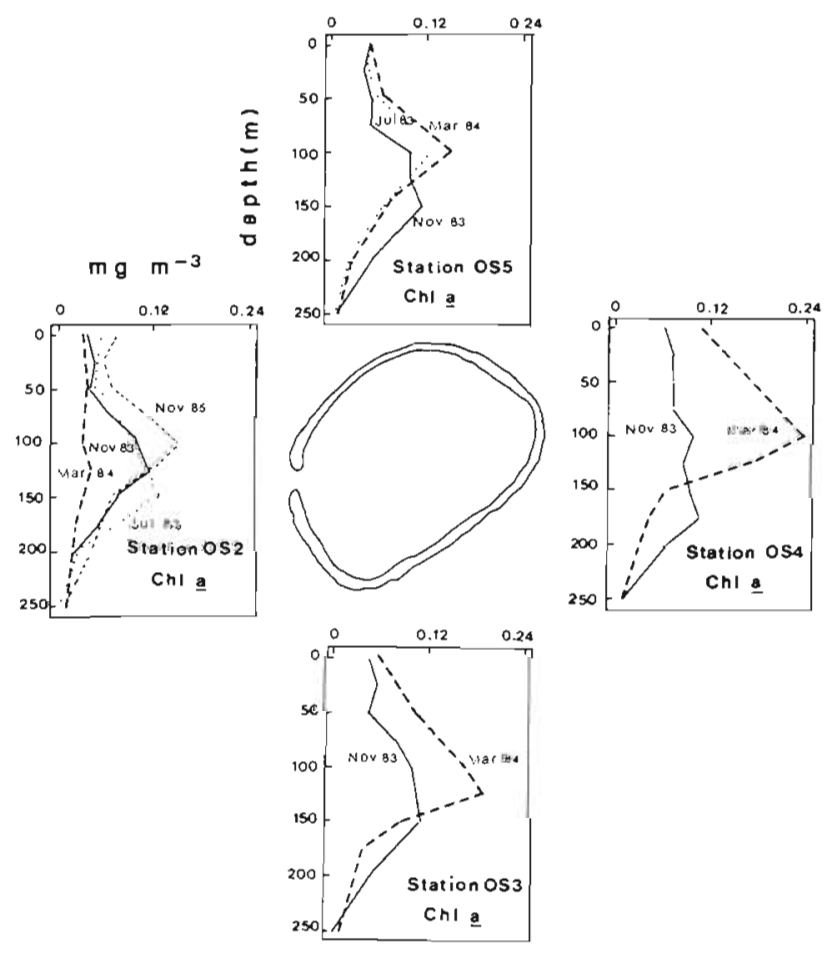

Fig. 2. Chlorophyll a ( $\mathrm{chl}$ a) concentration profiles $\left(\mathrm{mg} \mathrm{mm}^{-3}\right)$ at oceanic stations near Tikehau

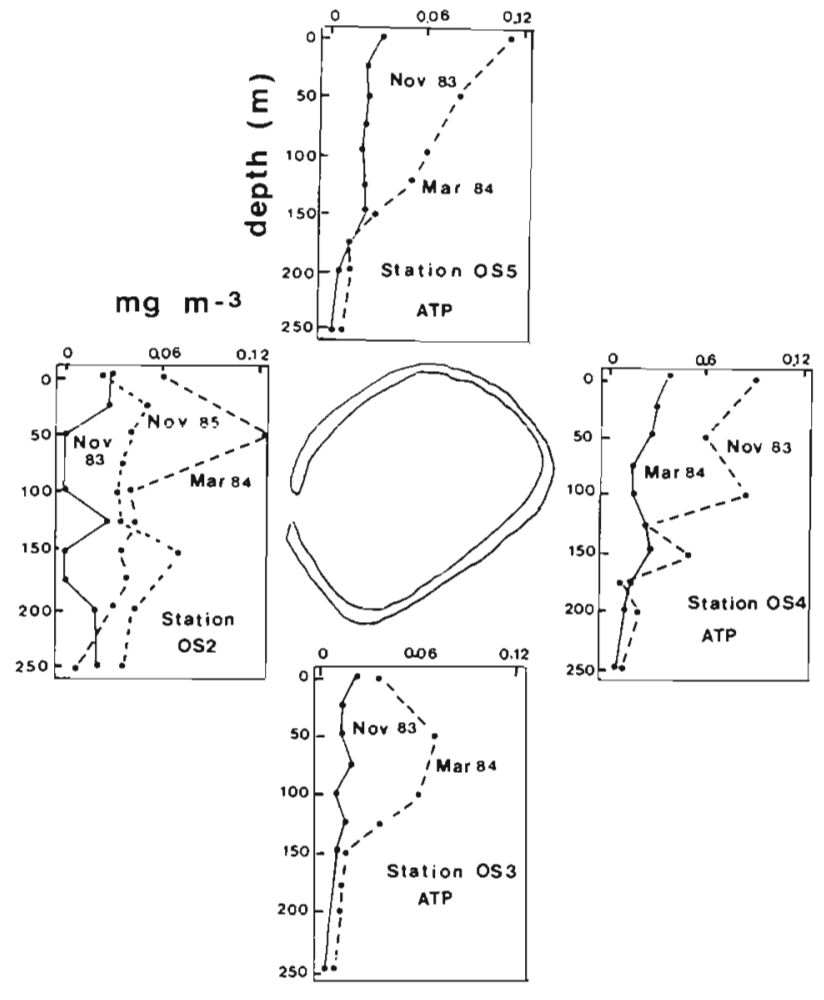

Fig. 3. ATP concentration profiles $\left(\mathrm{mg} \mathrm{m}^{-3}\right)$ at oceanic stations near Tikehau

with the $500 \mathrm{ml}$ aliquots; pigment concentrations were measured on the $200 \mathrm{ml}$ aliquots.

Concentrations of chl $a$, phaeo $a, \mathrm{ATP}, \mathrm{POC}, \mathrm{PON}$ and POP were measured at $15 \mathrm{~m}$, at the beginning of the experiment.

The trapping rate $(T R)$ was calculated by the equation:

$$
T R\left(\mathrm{mg} \text { POM m } \mathrm{m}^{-2} \mathrm{~d}^{-1}\right)=\frac{\left(C_{\mathrm{T}}-C_{\mathrm{w}}\right) \times V}{\Delta t \times S}
$$

where $C_{\mathrm{T}}=$ POM concentration in the trap $\left(\mathrm{mg} \mathrm{m}^{-3}\right)$; $C_{w}=$ POM concentration in the water at $15 \mathrm{~m}$ (mg $\left.\mathrm{m}^{-3}\right) ; V=$ trap volume $\left(\mathrm{m}^{3}\right) ; \Delta t=$ time interval $(\mathrm{d}) ; S=$ collecting surface area of the trap $\left(\mathrm{m}^{2}\right)$.

Assuming that the trapped population of particles is a subset of the suspended population, the settling velocity (SV) can be obtained by the equation:

$$
S V\left(\mathrm{~m} \mathrm{~d}^{-1}\right)=T R / C_{w} .
$$




\section{RESULTS AND DISCUSSION}

\section{POM in oceanic waters}

Chlorophyll profiles (Fig. 2) show deep maxima at depths between 100 and $200 \mathrm{~m}$. Concentrations here could reach $0.24 \mathrm{mg} \mathrm{m}^{-3}$ in March 1984 (spring) when chl a concentrations in the water column were higher than in other months.

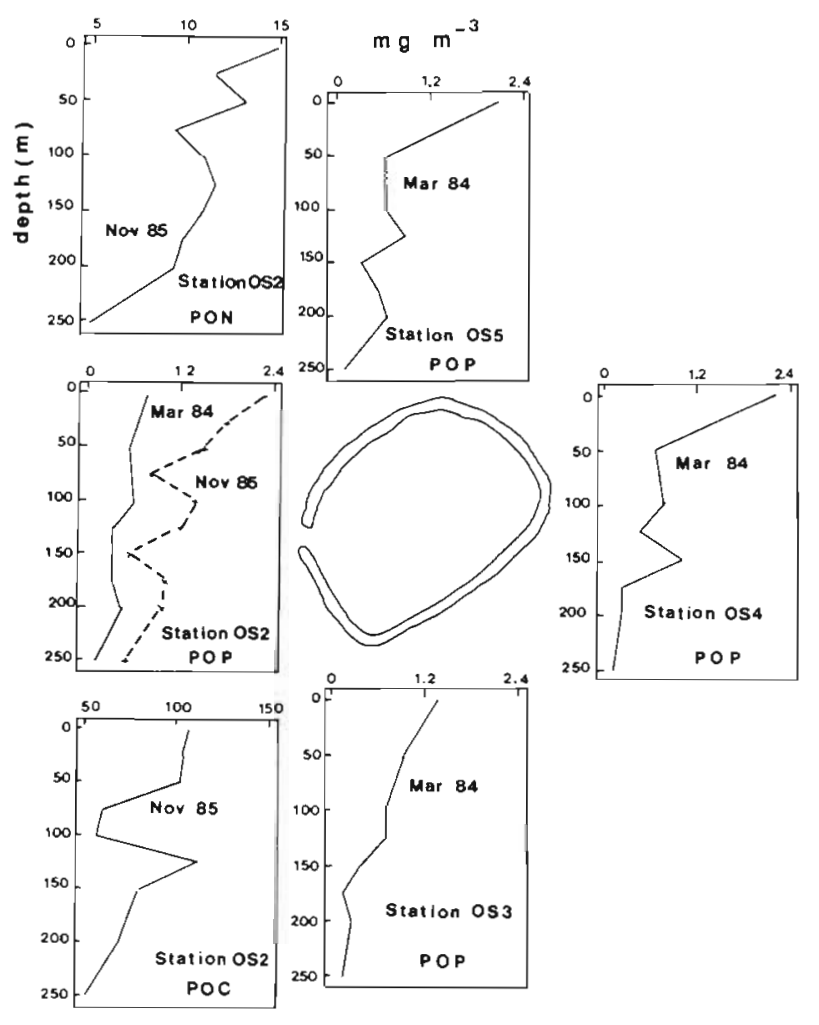

Fig. 4. Particulate organic phosphorus, carbon and nitrogen (POP, POC and PON) concentration profiles $\left(\mathrm{mg} \mathrm{m}^{-3}\right)$ at oceanic stations near Tikehau

ATP concentrations (Fig. 3) were highest in the upper $100 \mathrm{~m}\left(0.05\right.$ to $\left.0.12 \mathrm{mg} \mathrm{m}^{-3}\right)$ and also higher in March than in November. We did not observe differences between stations.

POP concentrations (Fig. 4) generally decreased with depth. High values observed in surface water at Stns OS4 and OS5 in March 1984 were probably due to detritus export from the reef flat.

All parameters were measured in November 1985 at Stn OS2; however, at that time, this station, located opposite the passage, was influenced by a strong lagoonal water discharge.
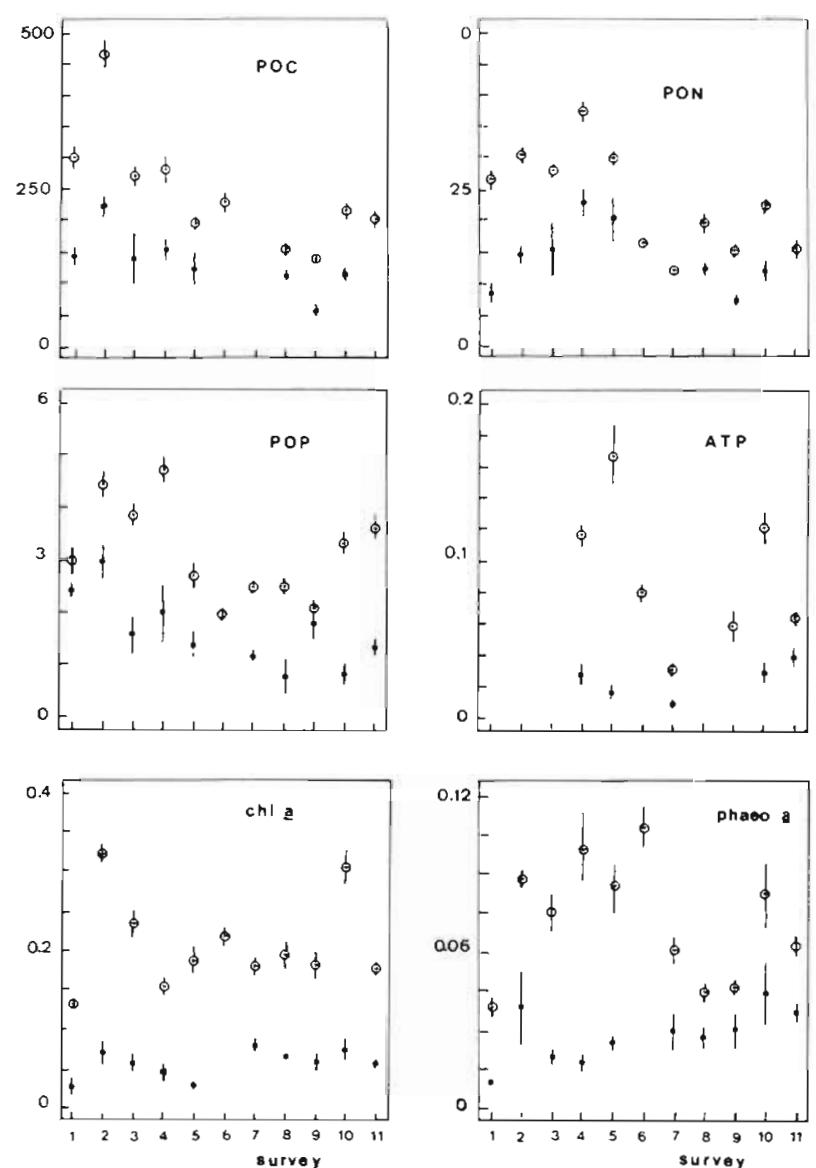

Fig. 5. Mean ( \pm SE) POC, PON, POP, ATP and pigment concentrations in lagoon of Tikehau Atoll as a function of survey of sampling $\odot$ : lagoon; •: Stn 051

\section{POM in the lagoon and at Stn OS1}

\section{Survey variability}

Average POC, PON, POP, ATP and pigment concentrations in samples taken during the 11 surveys in the lagoon and at Stn OS1 (all stations and depths included) are presented in Fig. 5. The low level of the standard error observed during the surveys demonstrates the relative homogeneity of POM distribution inside the lagoon. Average POC concentration in the lagoon was highest in July 1983 (466 $\pm 23 \mathrm{mg} \mathrm{m}^{-3}$; mean $\pm \mathrm{SE}$ ). The occurrence of 2 hurricanes (end of March and May 1983) in the western Tuamotu Archipelago is believed to have been responsible for this high POC level. During the other surveys, average POC concentrations were in the range 137 to $301 \mathrm{mg}$ $\mathrm{m}^{-3}$. Average $\mathrm{PON}$ concentration was highest in December $1983\left(37 \pm 2 \mathrm{mg} \mathrm{m}^{-3}\right)$ and lowest in August $1985\left(15 \pm 1 \mathrm{mg} \mathrm{m}^{-3}\right)$. Average POP concentration was 
highest in July $\left(4.7 \pm 0.3 \mathrm{mg} \mathrm{m}^{-3}\right)$ and December 1983 $\left(4.5 \pm 0.3 \mathrm{mg} \mathrm{m}^{-3}\right)$ and lowest in November $1984(2 \pm$ $\left.0.1 \mathrm{mg} \mathrm{m}^{-3}\right)$ and April 1985 (2.1 $\left.\pm 0.2 \mathrm{mg} \mathrm{m}^{-3}\right)$. ATP concentration was measured during 7 surveys and its average was highest in February $1984(0.17 \pm 0.019 \mathrm{mg}$ $\left.\mathrm{m}^{-3}\right)$ and lowest in January $1985(0.03 \pm 0.003 \mathrm{mg}$ $\mathrm{m}^{-3}$ ). Average chlorophyll concentration was highest in July 1983 (0.32 $\left.\pm 0.01 \mathrm{mg} \mathrm{m}^{-3}\right)$ and July 1985 (0.31 \pm $0.01 \mathrm{mg} \mathrm{m}^{-3}$ ). During the other surveys, the average was in the range 0.13 to $0.23 \mathrm{mg} \mathrm{m}^{-3}$. Average phaeophytin concentration was in the range 0.04 to $0.11 \mathrm{mg} \mathrm{m}^{-3}$.

The level of POM concentration observed at Stn OS1 is correlated with the level of POM concentration observed in lagoonal waters. This is more evident for POC ( $\mathrm{r}=0.94, \mathrm{p}=0.0005)$ and PON ( $\mathrm{r}=0.86, \mathrm{p}=$ $0.006)$ but is also true for chl $a(r=0.59)$ and POP $(r=$ 0.50). Therefore, the POM water content of Stn OS1 was influenced by the lagoonal discharge. Quasim \& Sankaranaryanan (1970) observed a similar feature: POC concentration $2 \mathrm{~km}$ from the Karavatti Atoll (Laccadives) was 3 times higher than POC concentration $12 \mathrm{~km}$ seawards. We can estimate the average POC and PON concentrations in oceanic waters when the lagoonal discharge is zero by the intercepts of the regression lines: POC concentration at Stn OS1 versus POC concentration in the lagoon (58 $\left.\pm 26 \mathrm{mg} \mathrm{C} \mathrm{m}^{-3}\right)$, and PON concentration at Stn OS1 versus PON concentration in the lagoon $\left(6 \pm 3 \mathrm{mg} \mathrm{N} \mathrm{m}^{-3}\right)$. The POP concentration in oceanic waters can be calculated from the POP average concentration measured in the upper $100 \mathrm{~m}$ depths at oceanic stations prospected in March $1984\left(0.7 \pm 0.3 \mathrm{mg} \mathrm{P} \mathrm{m}^{-3}\right)$

\section{Bottom influence}

In samples taken near the bottom, we observed an increase of $37 \%$ for POC, $27 \%$ for PON, $31 \%$ for POP, $32 \%$ for chl a, $43 \%$ for phaeo a and $1 \%$ for ATP (Table 3$)$. The POM increase is probably due to resuspension of detritus. Gerber \& Marshall (1982) observed in Enewetak lagoon that particulate carbon and nitrogen were higher in samples collected at 30 to $35 \mathrm{~m}$ than at the surface; they suggested that reef detritus settles and accumulates in the deeper water.

\section{Lagoon reference station}

Concentrations of POC, PON, POP, ATP and pigments in samples taken in the water column at stations prospected during the surveys (except Faufaa station) were not significantly different (significance level $>0.05)$ from samples taken in the water column at Faufaa Station (Table 4). Therefore, the Faufaa Station may be considered as a good lagoon reference station. This station was intensively sampled between

Table 3. Comparisons between samples taken in the water column and in the bottom layer. $\overline{\mathrm{X}}$ : mean value; DBM: difference between means, \%: DBM $\times 100 / \bar{X}$ of the water column; SL: significance level; $\mathrm{n}$ : no. of samples

\begin{tabular}{|lccccccccc}
\hline Variable & $\overline{\mathrm{X}}$ & $\begin{array}{c}\text { Water column } \\
\pm \mathrm{SD}\end{array}$ & $\mathrm{n}$ & $\overline{\mathrm{X}}$ & $\begin{array}{c}\text { Bottom layer } \\
\pm \mathrm{SD}\end{array}$ & $\mathrm{n}$ & DBM & S \\
\hline POC & 208 & \pm 102 & 391 & 285 & \pm 149 & 80 & 76 & 37 & $<10^{-3}$ \\
PON & 24 & \pm 13 & 390 & 21 & \pm 10 & 80 & 6.3 & 27 & $<10^{-3}$ \\
POP & 2.9 & \pm 1.4 & 328 & 2.7 & \pm 1.6 & 88 & 0.9 & 31 & $<10^{-3}$ \\
ATP & 0.09 & \pm 0.06 & 201 & 0.09 & \pm 0.06 & 46 & 0.001 & 1 & $=0.9$ \\
Chl $a$ & 0.19 & \pm 0.07 & 511 & 0.25 & \pm 0.16 & 83 & 0.06 & 32 & $<10^{-3}$ \\
Phaeo a & 0.07 & \pm 0.04 & 534 & 0.10 & \pm 0.09 & 92 & 0.03 & 43 & $<10^{-3}$ \\
\hline
\end{tabular}

Table 4. Comparisons between samples taken in the water column at stations studied during the 11 surveys and at Faufaa (1983 to 1985). $\bar{X}$ : mean value; DBM: difference between means, SL: significance level; n: no. of samples

\begin{tabular}{|c|c|c|c|c|c|c|c|c|}
\hline Variable & $\bar{x}$ & $\begin{array}{l}\text { rvey stati } \\
\pm \mathrm{SD}\end{array}$ & n & $\overline{\mathrm{X}}$ & $\begin{array}{c}\text { If a Sta } \\
\pm S D\end{array}$ & $\mathrm{n}$ & DBM & $\mathrm{SL}$ \\
\hline POC & 226 & \pm 119 & 170 & 202 & \pm 81 & 85 & 24 & 0.09 \\
\hline PON & 24 & \pm 12 & 170 & 20 & \pm 9 & 84 & 4 & 0.06 \\
\hline POP & 2.9 & \pm 1.4 & 197 & 2.9 & \pm 1.4 & 88 & 0.02 & 0.92 \\
\hline ATP & 0.09 & \pm 0.07 & 93 & 0.08 & \pm 0.05 & 76 & 0.006 & 0.54 \\
\hline Chl a & 0.19 & \pm 0.06 & 189 & 0.22 & \pm 0.11 & 104 & 0.03 & 0.11 \\
\hline Phaeo a & 0.06 & \pm 0.04 & 210 & 0.07 & \pm 0.04 & 104 & 0.003 & 0.57 \\
\hline
\end{tabular}




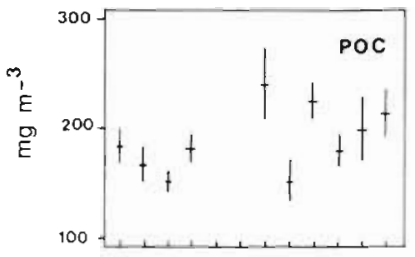

month

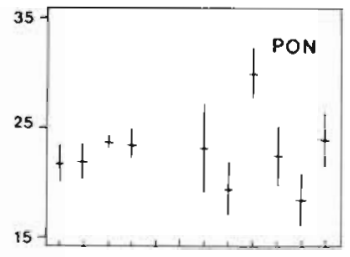

month
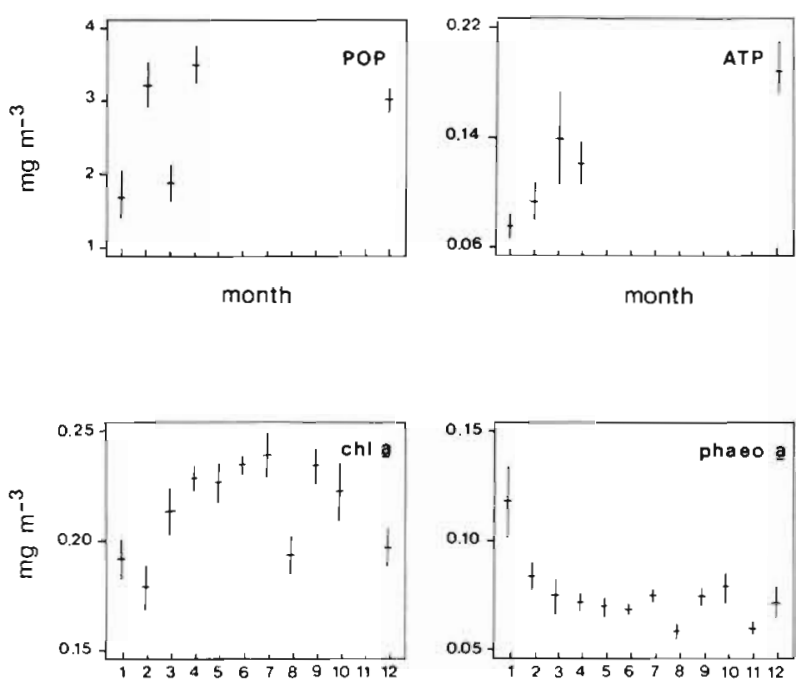

month

month

Fig. 6. Mean ( \pm SE) POC, PON, POP, ATP and pigment concentrations at Faufaa between November 1985 and February 1987

November 1985 and February 1987 with a view to observing a possible cycle in POM concentration. Monthly average POC concentration (Fig. 6) was in the range 150 to $240 \mathrm{mg} \mathrm{C} \mathrm{m}^{-3}$, with a maximum in July (southern winter). In Enewetak, Gerber \& Marshall (1982) observed that detritus concentration was lower in winter than in summer and they thought that it may be due to difference in residence tume of the lagoon waters (200 d in summer and 20 to $30 \mathrm{~d}$ in winter). In Tikehau, lagoonal water residence time was higher in summer (230 d) than in winter (100 d) (Lenhardt 1988); therefore, differences in residence time of Tikehau lagoonal waters were not responsible for differences in POC concentration.

\section{Comparison with other atoll lagoons}

To enable comparison of POM content for Tikehau lagoon water, we average 1984 to 1987 data obtained in the water column: $\mathrm{POC}=192 \pm 5, \mathrm{PON}=21 \pm 1$ and $\mathrm{POP}=2.7 \pm 0.1$. Apparently there is no relation between residence time of waters in atoll lagoons and their POM content (Table 5). Absolute values of POM concentrations are very different; the variability in measurements of fluxes reflect not only natural variability in these parameters, but also major errors associated with the methods employed (Hatcher 1983).

\section{POM export from lagoon to ocean}

Exports (EX) of POC, PON and POP from the lagoon to the ocean can be calculated by the equation:

$$
E x\left(\mathrm{mg} \mathrm{m}^{-2} \mathrm{~d}^{-1}\right)=\frac{F \times C_{L}}{L_{\mathrm{s}}}
$$

where $F\left(\mathrm{~m}^{3} \mathrm{~d}^{-1}\right)=$ monthly average flow through the lagoon passage and the reef-flat spillways (given by Lenhardt 1988); $L_{s}=$ lagoon surface area $(=4 \times$ $10^{8} \mathrm{~m}^{2}$ ); and $C_{\mathrm{L}}=$ monthly average concentration of POC, PON or POP in the lagoon. Results appear in Table 6 . Compared with other lagoonal carbon fluxes, the average POC export (26.3 $\mathrm{mg} \mathrm{C} \mathrm{m}^{-2} \mathrm{~d}^{-1}$ ) was low: $6 \%$ of the phytoplankton production (440 $\mathrm{mg} \mathrm{C} \mathrm{m}^{-2} \mathrm{~d}^{-1}$ ) given by Charpy-Roubaud et al. (1989) and $8 \%$ of the

Table 5. Particulate organic carbon ( $\mathrm{POC} ; \mathrm{ng} \mathrm{C}^{-3}$ ) in coral reef lagoon waters. RT: residence time in days. Taken in part from Hatcher (1983) and Marshall et al. (1975)

\begin{tabular}{|lcccl|}
\hline Lagoon & RT & \multicolumn{2}{c|}{ POC } & Source \\
& & Lagoon & Ocean & \\
\hline Tikehau Atoll & 176 & 192 & 52 & This study \\
Enewetak Atoll & $20-200$ & $20-50$ & $18-30$ & Gerber \& Marshall (1982) \\
Fanning Atoll & 30 & 80 & & Gordon (1971), Smith \& Pesret (1974) \\
Canton Atoll & $50-95$ & $160^{\text {a }}$ & & Smith \& Jokiel (1975a, b) \\
Kavarati Atoll & & 355 & 75 & Quasim \& Sankaranarayanan (1970) \\
Houtman Atoll & & $1560-3660$ & $14-42$ & Hatcher (1983) \\
South Caicos & 420 & 40 & Marshall et al. (1975) \\
Kanohe Bay & $82-116$ & $185-243$ & Coles \& Strathman (1973) \\
Lizard Island & & & \\
a Value derived by chl $a \times 200$ & & & \\
\hline
\end{tabular}


Table 6. Monthly average flow through the lagoon passage and the reef-flat spillways $\left(F_{;} \mathrm{m}^{3} \times 10^{-6} \mathrm{~d}^{-1}\right)$ calculated from Lenhardt (1988), and export $\left(E x_{i} \mathrm{mg} \mathrm{m}^{-2} \mathrm{~d}^{-1}\right)$ of POC, PON and POP from the lagoon to the ocean between 1985 and 1987

\begin{tabular}{|lcccc|}
\hline Date & $F$ & \multicolumn{3}{c|}{$\begin{array}{c}\text { Ex } \\
\text { PON }\end{array}$} \\
\hline Mar 1985 & 43.2 & 16.7 & 2.1 & POP \\
Apr 1985 & 60.5 & 20.7 & 2.3 & 0.27 \\
Jul 1985 & 86.4 & 46.4 & 4.8 & 0.72 \\
Sep 1985 & 77.8 & 43.8 & 5.8 & - \\
Oct 1985 & 60.5 & 32.7 & 4.7 & - \\
Jan 1986 & 34.6 & 17.5 & 2.0 & 0.15 \\
Oct 1986 & 60.5 & 22.1 & 2.1 & - \\
Nov 1986 & 60.5 & 30.1 & 2.7 & - \\
Jan 1987 & 38.9 & 13.4 & 1.7 & - \\
Feb 1987 & 34.6 & 20.0 & 2.5 & - \\
Average: & 55.8 & 26.3 & 3.1 & 0.37 \\
\hline
\end{tabular}

ingestion by the zooplankton ( $314 \mathrm{mg} \mathrm{C} \mathrm{m}^{-2} \mathrm{~d}^{-1}$ ) measured by Le Borgne et al. (1989). In Canton Atoll, Smith \& Jokiel (1975b) observed a POC export of 6 to $20 \mathrm{mg} \mathrm{C}$ $\mathrm{m}^{-2} \mathrm{~d}^{-1}$ which represented 0.1 to $0.3 \%$ of the lagoonal gross organic carbon production $\left(6 \mathrm{~g} \mathrm{C} \mathrm{m}^{-2} \mathrm{~d}^{-1}\right)$. These export rates are quite similar in spite of different residence time ( $50 \mathrm{~d}$ in Canton and $176 \mathrm{~d}$ in Tikehau) and different lagoonal primary productions $\left(6 \mathrm{~g} \mathrm{C} \mathrm{m}^{-2} \mathrm{~d}^{-1}\right.$ in Canton and $0.7 \mathrm{~g} \mathrm{C} \mathrm{m}^{-2} \mathrm{~d}^{-1}$ in Tikehau).

\section{POM size and composition}

To measure the size structure of suspended particles, water samples were successively filtered through a polyamide net with a $35 \mu \mathrm{m}$ size mesh, through a $5 \mu \mathrm{m}$ filter (Millipore), then through a $1.2 \mu \mathrm{m}$ filter (Millipore) and finally through a GF/F (Whatman) filter. A significant part of the POM was in the 0.4 to $1.2 \mu \mathrm{m}$ size class ( 1 to $48 \%$ of the ATP, 36 to $65 \%$ of the POP, 33 to $52 \%$ of the POC and 18 to $22 \%$ of the PON) (Table 7 ). The results of 7 filtering experiments performed in 1984,
1985 and 1986 with $35 \mu \mathrm{m}$ mesh size (polyamide net) and then $5 \mu \mathrm{m}$ and $3 \mu \mathrm{m}$ pore size (Nuclepore filters) (Table 8 ) indicate that about $50 \%$ of the POM is constituted of particles smaller than $5 \mu \mathrm{m}$, regardless of the variable considered.

The size composition of POM was studied in April 1986: particles $<3 \mu \mathrm{m}$ accounted for $81 \%$ of the POC and detritus comprised $82 \%$ of the total POM. Phytoplankton accounted for $35 \%$ of the living carbon with a strong dominance of cyanobacteria; heteroflagellates and ciliates accounted for $6 \%$ of the living $C$ (Blanchot et al. 1989).

\section{Sedimentation of particles}

The sediment trap was placed at a depth thought to be far enough from the bottom $(5 \mathrm{~m})$ to collect only material sinking from the surface layer. Current speeds below $5 \mathrm{~m}$ depth in the lagoon are generally lower than $5 \mathrm{~cm} \mathrm{~s}^{-1}$ (Lenhardt 1988). Therefore, we assume that resuspension rate $=0$ and that the trapping efficiency was maximum. So sedimentation rate $(S R)=$ trapping rate $(T R)$. Results appear in Table 9.

The vertical flux of POC lies within the range of the sedimentation rate expected for coastal waters (Mann 1982). The $S R$ s of carbon and nitrogen (350 and $36 \mathrm{mg}$ $\mathrm{m}^{-2} \mathrm{~d}^{-1}$ ) are close to the values given by Taguchi (1982) for Kaneohe Bay (Hawaii); however, these values are 4 times lower than the values given by Koop \& Larkum (1987) for organic $\mathrm{C}$ and $\mathrm{N}$ deposition in the lagoon of One Tree Island (Great Barrier Reef) and 2.4 times lower than the POC deposition rate given by Chardy \& Clavier (1989) for the southwest lagoon of New Caledonia ( $844 \mathrm{mg} \mathrm{C} \mathrm{m}^{-2} \mathrm{~d}^{-1}$ ). There is a great difference between the deposition rate calculated, for the Canton lagoon, by Smith \& Jokiel (1975b): $10 \mathrm{mg} \mathrm{C}$ $\mathrm{m}^{-2} \mathrm{~d}^{-1}$ and our data; however, they used for their calculation a percentage of organic carbon in suspended material equal to that observed in sediments $(0.8 \%)$ even when this percentage was equal to $9 \%$ in

Table 7. Relative abundance of POM among the 3 size fractions ( $\mu \mathrm{m})$ at Faufaa on 23 November ( 0 and $10 \mathrm{~m}$ ) and 24 November $1984,(0,2,10$ and $15 \mathrm{~m})$

\begin{tabular}{|c|c|c|c|c|c|c|c|c|c|c|c|c|}
\hline \multirow{2}{*}{$\begin{array}{l}\text { Depth } \\
\text { (m) }\end{array}$} & \multicolumn{3}{|c|}{ ATP $(\%)$} & \multicolumn{3}{|c|}{ POP (\%) } & \multicolumn{3}{|c|}{$\operatorname{POC}(\%)$} & \multicolumn{3}{|c|}{ PON (\%) } \\
\hline & $<1.2$ & $2-5$ & $5-35$ & $<1.2$ & $2-5$ & $5-35$ & $<1.2$ & $2-5$ & $5-35$ & $<1.2$ & $2-5$ & $5-35$ \\
\hline 0 & 15 & 30 & 55 & 65 & 29 & 6 & 35 & 0 & 65 & 18 & 6 & 76 \\
\hline 10 & 48 & 0 & 52 & 36 & 20 & 44 & 33 & 1 & 65 & 20 & 5 & 75 \\
\hline 0 & 29 & 45 & 26 & 65 & - & - & 52 & 25 & 23 & 27 & 27 & 46 \\
\hline 2 & 1 & 17 & 82 & - & - & - & - & - & - & - & - & - \\
\hline 10 & 11 & 14 & 75 & - & - & - & - & - & - & - & - & - \\
\hline 15 & 3 & 26 & 71 & 65 & 24 & 12 & 34 & 25 & 41 & 22 & 44 & 34 \\
\hline
\end{tabular}


Table 8. Means ( \pm SE) of POM passing through a $5 \mu \mathrm{m}$ (1984 and 1985) or $3 \mu \mathrm{m}$ (1986) pore filter as a percentage of total POM at Faufaa. Standard errors of samples taken at the same date are given

\begin{tabular}{|c|c|c|c|c|c|c|c|}
\hline Date & $\begin{array}{l}\text { Depth } \\
(\mathrm{m})\end{array}$ & $\begin{array}{c}\text { Chl a } \\
(\%)\end{array}$ & $\begin{array}{c}\text { Phaeo a } \\
(\%)\end{array}$ & $\begin{array}{l}\text { ATP } \\
(\%)\end{array}$ & $\begin{array}{c}\text { POC } \\
(\%)\end{array}$ & $\begin{array}{c}\text { PON } \\
(\%)\end{array}$ & $\begin{array}{l}\text { POP } \\
(\%)\end{array}$ \\
\hline 23 Nov 1984 & 0,10 & - & - & $47 \pm 2$ & $35 \pm 0$ & $24 \pm 1$ & $75 \pm 19$ \\
\hline 24 Nov 1984 & $0,2,10,15$ & $66 \pm 5$ & - & $48 \pm 26$ & $61 \pm 7$ & $57 \pm 3$ & 88 \\
\hline 2 Apr 1985 & $0,5,10,15,19$ & $57 \pm 25$ & $40 \pm 35$ & - & $43 \pm 14$ & $55 \pm 23$ & $27 \pm 7$ \\
\hline 9 Apr 1985 & $0,5,10,15,19$ & $32 \pm 6$ & $29 \pm 17$ & $68 \pm 11$ & $33 \pm 11$ & $46 \pm 16$ & $47 \pm 20$ \\
\hline 12 Jul 1985 & 0 & 57 & 34 & 30 & 35 & 32 & 29 \\
\hline 13 Aug 1985 & $0,2,4,6,8,10,15$ & $25 \pm 4$ & - & $20 \pm 5$ & - & - & $24 \pm 12$ \\
\hline 7 Apr 1986 & $0,5,10,19$ & $92 \pm 5$ & $74 \pm 3$ & $75 \pm 24$ & $81 \pm 1$ & $77 \pm 13$ & $99 \pm 2$ \\
\hline Average $\pm \mathrm{SE}$ & & $50 \pm 6$ & $45 \pm 8$ & $46 \pm 6$ & $50 \pm 6$ & $54 \pm 5$ & $49 \pm 6$ \\
\hline
\end{tabular}

suspended matter $(0.7$ to $35 \mu \mathrm{m})$ of Tikehau lagoon (Blanchot et al. 1989).

The mean sedimentation rate of total pigments: $0.23 \mathrm{mg} \mathrm{m}^{-2} \mathrm{~d}^{-1}$ is 4 times lower than the $S R$ given by Taguchi (1982) in Kaneohe Bay (Hawaii) and 4 times lower than the chl a deposition rate calculated from Chardy \& Clavier (1989) in New Caledonia.

The settling velocity of chl a $\left(0.6 \mathrm{~cm} \mathrm{~d}^{-1}\right)$ is comparable to that of the nanoplankton measured in the Hawaiian waters (Takahashi \& Bienfang 1983); but it is only half the phaeo a settling velocity. In general, phaeo $a$ in suspended particles has been attributed to microzooplankton grazing (SooHoo \& Kiefer 1982), while that in sinking material caught in sediment traps has been attributed to macrozooplankton grazing (e.g. Lorenzen et al. 1983).
The average POC:PON:POP ratio (mass) in the trapped material was $117: 12: 1$ (i.e. $\mathrm{C}: \mathrm{N}: \mathrm{P}=$ $302: 27: 1$, molar basis); in suspended material, during the time of trapping experiments, the POC: PON : POP ratio (mass) was 68:7:1 (i.e. $\mathrm{C}: \mathrm{N}: \mathrm{P}=176: 17: 1$, molar basis). The trapped material had the same ratio $C: N(9.8)$ as the suspended particles (10) but its $C: P$ ratio (117) was higher than the $C: P$ ratio (68) in suspended particles. The loss of phosphorus in the trapped material indicates that the organic matter was dead; this is confirmed by ATP measurements in trapping material which were all zero.

However, TR measurements were performed on 14 occasions at only one station and one depth; therefore, average sedimentation rates are perhaps not representative of lagoon POM sedimentation. Nonetheless, we

Table 9. Trapping rate $\left(T R ; \mathrm{mg} \mathrm{m} \mathrm{m}^{-2} \mathrm{~d}^{-1}\right)$, settling velocities $\left(S V ; \mathrm{m} \mathrm{d}^{-1}\right)$ and $\mathrm{C}: \mathrm{N}: \mathrm{P}$ ratio $(\mathrm{w} / \mathrm{w})$ of trapped material measured at Faufaa. CV: coefficient of variation $(\%)$

\begin{tabular}{|c|c|c|c|c|c|c|c|c|c|c|c|}
\hline \multirow[t]{2}{*}{ Date } & \multicolumn{2}{|c|}{ Chl a } & \multicolumn{2}{|c|}{ Phaeo a } & \multicolumn{2}{|c|}{ POP } & \multicolumn{2}{|c|}{ POC } & \multicolumn{2}{|c|}{ PON } & \multirow[t]{2}{*}{$\mathrm{C}: \mathrm{N}: \mathrm{P}$} \\
\hline & $T R$ & $V S$ & $T R$ & VS & $T R$ & VS & $T R$ & $V S$ & $T R$ & $V S$ & \\
\hline $7 \operatorname{Jan} 1986$ & 0.09 & 0.6 & 0.14 & 1.2 & 3.6 & 2.0 & 254 & 1.4 & 19 & 1.0 & $71: 5: 1$ \\
\hline $8 \operatorname{Jan} 1986$ & 0.07 & 0.5 & 0.14 & 1.2 & 5.0 & 2.7 & 456 & 2.6 & 58 & 3.2 & $91: 12: 1$ \\
\hline $12 \operatorname{Jan} 1986$ & 0.06 & 0.4 & 0.05 & 0.6 & 7.2 & 6.6 & 941 & 8.2 & 79 & 5.4 & $131: 11: 1$ \\
\hline 16 Jan 1986 & 0.24 & 1.7 & 0.08 & 0.7 & 7.9 & 3.3 & 1032 & 9.0 & 113 & 7.5 & $131: 14: 1$ \\
\hline 25 Jan 1986 & 0.06 & 0.5 & 0.06 & 1.3 & 0.7 & 0.1 & 266 & 1.7 & 22 & 1.2 & $380: 31: 1$ \\
\hline $17 \operatorname{Dec} 1986$ & 0.21 & 1.2 & 0.11 & 2.7 & 3.8 & 1.2 & 130 & 1.0 & 12 & 0.9 & $34: 3: 1$ \\
\hline $18 \operatorname{Dec} 1986$ & 0.15 & 0.6 & 0.14 & 2.3 & 3.4 & 1.1 & 122 & 1.2 & 12 & 1.0 & $36: 4: 1$ \\
\hline 20 Dec 1986 & 0.15 & 0.8 & 0.19 & 3.9 & 6.2 & 3.0 & 146 & 0.6 & 14 & 0.6 & $24: 2: 1$ \\
\hline $22 \operatorname{Dec} 1986$ & 0.14 & 0.6 & 0.13 & 1.7 & 4.6 & 1.5 & 221 & 1.4 & 24 & 1.8 & $48: 5: 1$ \\
\hline 9 Feb 1987 & 0.18 & 0.6 & 0.31 & 0.2 & 2.4 & 1.7 & - & - & - & - & - \\
\hline 10 Feb 1987 & 0.19 & 0.7 & 0.22 & 2.0 & 1.4 & 1.2 & - & - & - & - & - \\
\hline 12 Feb 1987 & 0.20 & 0.8 & 0.26 & 2.4 & 1.4 & 1.2 & - & - & - & - & - \\
\hline 26 May 1987 & 0.05 & 0.3 & 0.08 & 1.4 & 0.5 & 0.2 & - & - & - & - & - \\
\hline 27 May 1987 & 0.00 & 0.0 & 0.00 & 0.0 & 0.5 & 0.1 & - & - & - & - & - \\
\hline 14 Jul 1987 & 0.03 & 0.1 & 0.11 & 1.1 & 1.2 & 0.7 & 108 & 0.7 & 12 & 0.6 & $90: 10: 1$ \\
\hline 17 Jul 1987 & 0.01 & 0.1 & 0.01 & 0.1 & 0.7 & 0.1 & 175 & 0.9 & 22 & 0.8 & $250: 31: 1$ \\
\hline Average & 0.11 & 0.6 & 0.12 & 1.4 & 3.2 & 1.7 & 350 & 2.6 & 36 & 2.2 & $117: 12: 1$ \\
\hline $\mathrm{CV}$ & 66 & 72 & 67 & 74 & 78 & 25 & 94 & 116 & 97 & 104 & \\
\hline
\end{tabular}


can roughly compare the sedimentation rate with other fluxes measured in the lagoon: POC average $S R$ was in the same order of magnitude as phytoplankton production (Charpy-Roubaud et al. 1989) and zooplankton ingestion (Le Borgne et al. 1989), 1.4 times higher than the sandy microphyte production (Charpy-Roubaud 1988) and 13 times higher than the POC export calculated previously. For comparison, in Kaneohe Bay, Taguchi (1982) observed that the carbon sedimentation rate was equal to $42.5 \%$ of the phytoplankton production and to 7 times the POC export. In Canton Atoll lagoon, Smith \& Jokiel (1975b) calculated that the organic carbon deposition represented $0.2 \%$ of the gross lagoon production and between 2 and 0.5 times the POC export. In the southwest lagoon of New Caledonia, Chardy \& Clavier (1989) observed that benthic microflora production represented $21 \%$ of the input of organic carbon to the bottom.

Given this deposition of organic material in the lagoon, one would expect to find sediments with relatively high organic content. However, levels of organic material in coral-reef sediments are generally low, about $0.5 \%$ of dry weight (Vaugelas 1982 , Thomassin \& Cauwet 1985); this implies that organic material is rapidly consumed and/or remineralized (Hatcher 1983).

\section{Origin of lagoon POM}

Charpy \& Charpy-Roubaud (1990b) have shown that the detritus reef flat export towards the lagoon is insignificant and the detritus pool ( $84 \%$ of the POC) originates from lagoonal primary production. The phytoplanktonic production ingested and then excreted as feacal pellets by the zooplankton cannot alone explain the level of the POC sedimentation rate: export of POM from the lagoon pinnacles may be the other POC source.

Observed variations in POM content of lagoonal waters are probably not due to variation in primary production. Indeed, maximum POC concentrations were observed in winter when light energy was minimum. Storms are probably responsible for the increase in POM by removing organic matter from the pinnacles. On the other hand, grazing may have a significant effect on POM concentration: in April 1985, $30 \%$ of the POC content of lagoonal waters was ingested in $1 \mathrm{wk}$ during a bloom of Thalia democratica (Charpy et al. 1986).

\section{CONCLUSIONS}

The oceanic waters around the Tikehau atoll are enriched in POM by reef-flat detritus production and lagoonal discharge.
POM content of lagoonal waters is homogeneous in space but shows variations greater than $100 \%$ with time, probably due to resuspension during storms.

Average lagoonal POC concentration observed in Tikehau lies within the wide range of data recorded in other coral reef areas. There is no relation between residence time of oceanic waters in the lagoons and lagoonal POC content.

The POM is made up of small particles $150 \%$ are $<5 \mu \mathrm{m}$ ); this probably influences the composition of detritivores.

The sedimentation rate represents $80 \%$ of the phytoplankton production. The loss of phosphorus during sedimentation indicates that a non-negligible part of the organic matter is mineralized in the water column.

POM export represents only a small percentage of other lagoonal fluxes; therefore, the geomorphology of atolls (closed or open) probably has a light effect on the POM content of lagoonal waters.

\section{LITERATURE CITED}

Blanchot, J., Charpy, L., Le Borgne, R. (1989). Size composition of particulate organic matter in the lagoon of Tikehau atoll (Tuamotu archipelago). Mar. Biol. 102: 329-339

Chardy, P., Clavier, J. (1989). An attempt to estimate the carbon budget for the south west lagoon of New Caledonia. Proc. 6th int. Coral Reef Symp. 2: 541-546

Charpy, L. (1985). Distribution and composition of particulate organic matter in the lagoon of Tikehau (Tuamotu archipelago, French Polynesia). Proc. 5th int. Coral Reef Congr., Tahiti 3: 353-357

Charpy, L., Bonnet, S., Le Borgne, R. (1986). Environment, matière organique particulaire et production phytoplanctonique. In: Intes, A. (ed.) Contribution à l'étude de l'atoll de Tikéhau (archipel des Tuamotu, Polynésie Française). ORSTOM Tahiti, Notes et Doc. Océanogr. 28: 81-114.

Charpy, L., Charpy-Roubaud, C. J. (1990a). A model of the relationship between light and primary production in an atoll lagoon. J. mar. biol. Ass. U.K. 70:357-369

Charpy, L., Charpy-Roubaud, C. J. (1990b). Trophic structure and productivity of the lagoonal communities of Tikehau atoll (Tuamotu Archipelago, French Polynesia). Hydrobiologia 207: 43-52

Charpy-Roubaud, C. J. (1988). Production primaire des fonds meubles du lagon de Tikehau (Atoll des Tuamotu, Polynésie Française). Oceanologica Acta 11 (3): 241-248

Charpy-Roubaud, C. J., Charpy, L., Cremoux, J.-L. (1990). Nutrient budget of the lagoonal waters in an open South Pacific atoll (Tikehau, Tuamotu, French Polynesia). Mar. Biol. 107: 67-73

Charpy-Roubaud, C. J., Charpy, L., Lemasson, L. (1989). Benthic and planktonic primary production of an open atoll lagoon (Tikehau, French Polynesia). Proc. 6th int. Coral Reef Symp., Townsville 2: 551-556

Coles, S. L., Strathmann, R. (1973). Observations on coral mucus 'flocs' and their potential trophic significance. Limnol. Oceanogr. 18 (4): 673-678

Delesalle, B. (1985). Environmental survey of Mataiva Atoll. Tuamotu Archipelago, French Polynesia. Atoll Res. Bull. 286: $1-34$ 
Faure, G., Laboute, P. (1984). Formations récifales: I Définition des unités récifales et distribution des principaux peuplements de Sclératinaires. In: Intes, A. (ed.) Latoll de Tikehau (archipel des Tuamotu, Polynésie Française). Premiers résultats. ORSTOM Tahiti, Notes et Doc. Océanogr 22: $108-136$

Gardner, W. D. (1980). Field assessment of sediment traps. J. Mar Res. $38(1): 41-52$

Gerber, R. P., Marshall, N. (1982). Characterization of the suspended particulate organic matter and feeding by the lagoon zooplankton at Enewetak atoll. Bull. mar Sci. 32 (1): $290-300$

Gordon, D. C. Jr (1971). Organic carbon budget of Fanning Island lagoon. Pacif. Sci. 25: 222-227

Gordon, D. C. Jr, Sutcliffe, W. H. Jr (1973). A new dry combustion method for the simultaneous determination of total organic carbon and nitrogen in sea water. Mar. Chem. 1: $231-244$

Harmelin-Vivien, M. (1985). Atoll de Tikehau, Archipel des Tuamotu. Proc. 5th int. Coral Reef Congr., Tahiti 1 $211-268$

Hatcher, B. G. (1983). The role of detritus in the metabolism and secondary production of coral reef ecosystems. In: Baker, J. T et al. (eds.) Proc. Great Barrier Reef Conference. Australian Inst. Mar. Science, Townsville, p. 317-325

Holm-Hansen, O., Booth, C. R. (1966). The measurement of adenosine triphosphate in the ocean and its ecological significance. Limnol. Oceanogr 11:510-519

Intes, A. (1984). Présentation générale de l'atoll. In: Intes, A. (ed.) L'atoll de Tikehau (archipel des Tuamotu, Polynésie Française). Premiers résultats. ORSTOM Tahiti, Notes et Doc. Océanogr 22: 4-12

Kinsey, D. W. (1983). Standards performance in coral reef primary production and carbon turnover. In: Barnes, D. J. (ed.) Perspectives on coral reefs. Australian Inst. Mar Science, Townsville, p. 209-220

Koop, K., Larkum, A. W D. (1987). Deposition of organic material in a coral reef lagoon, One Tree Island, Great Barrier Reef. Estuar. coast. Shelf Sci. 25: 1-9

Le Borgne, R. P., Blanchot, J., Charpy, L. (1989). Zooplankton of the atoll of Tikehau (Tuamotu Archipelago) and its relationship to particulate matter. Mar. Biol. 102: 341-353

Lenhardt, X. (1987). Etude bathymetrique du lagon de l'atoll de Tikehau. ORSTOM Tahiti, Notes et Doc. ORSTOM Tahiti Ser Oceanogr. 35: 53-70

Lenhardt, X. (1988). Hydrodynamique des lagons d'atoll et d'île haute en Polynésie Française. Thèse du Museum National d'Histoire Naturelle, Paris

Lorenzen, C. J., Welschmeyer, N. A., Copping, A. E., Vernet M. (1983). Sinking rates of organic particles. Limnol. Oceanogr. 28: 766-769

Mann, K. H. (1982). Ecology of coastal waters. A systems approach. Univ. of California Press, Berkeley and Los Angeles

Marshall, N., Durbin, A. G., Gerber, R., Telek, G. (1975) Observations on particulate and dissolved organic matter

This article was submitted to the editor in coral reef areas. Int. Revue ges. Hydrobiol. 60 (3): 335-345

Menzel, D., Corwin, J. (1965). The measurement of total phosphorus in sea water based on the liberation of organically bound fraction by persulfate oxydation. Limnol. Oceanogr 10 (2): 280-282

Moriarty, D. J. W (1979). Biomass of suspended bacteria over coral reefs. Mar Biol. 53: 193-200

Quasim, S. Z., Sankaranarayanan, V N. (1970). Production of particulate organic matter by the reef of Kavaratti atoll (Laccadives). Limnol. Oceanogr. 15: 574-578

Smith. S. V., Jokiel, P. L. (1975a). Water composition and biochemical gradients in the Canton atoll lagoon: 1. Lagoon description; design of system analysis; salt and water budget. Mar. Sci. Comm. 1 (1): 75-100

Smith, S. V., Jokiel, P. L. (1975b). Water composition and biogeochemical gradients in the Canton atoll lagoon: 2. Budgets of phosphorus, nitrogen, carbon dioxide, and particulate materials. Mar Sci. Comm. 1 (2): 165-207

Smith, S. V., Pesret, F. (1974). Processes of carbon dioxide flux in the Fanning island lagoon. Pacif. Sci. 28 (3): 225-245

SooHoo, J. B., Kiefer, D. A. (1982). Vertical distribution of phaeopigments. 1. A simple grazing and photo-oxidative scheme for small particles. Deep Sea Res. 29: 1539-1551

Sournia, A. (1976). Primary production of the lagoon of an atoll and the role of Foraminiferan symbionts. Mar. Biol. 37: $29-32$

Sournia, A., Ricard, M. (1975). Production primaire planctonique dans deux lagons de Polynésie Française (île de Moorea et atoll de Takapoto). C. R. hebd. Séanc. Acad. Sci. Paris, Ser. D 280 (6): 741-743

Sournia, A., Ricard, M. (1976). Données sur l'hydrologie et la productivité du lagon d'un atoll fermé (Takapoto, Iles Tuamotu). Vie et Milieu 26: 243-279

Strickland, J. D. H., Parsons, T. R. (1972). A practical handbook of seawater analysis (2nd edn). Bull. Fish. Res. Bd Can. 167: 1-311

Taguchi, S. (1982). Sedimentation of newly produced particulate organic matter in a subtropical inlet, Kaneohe Bay, Hawaii. Estuar coast. Shelf Sci. 14: 533-544

Takahashi, M., Bienfang, P. K. (1983). Size structure of phytoplankton biomass and photosynthesis in subtropical Hawailan waters. Mar Biol. 76: 203-211

Telek, G., Marshall, N. (1974). Using a CHN analyser to reduce carbonate interference in particulate organic carbon analysis. Mar. Biol. 24: 219-221

Thomassin, B., Cauwet, G. (1985). Organic matter distribution in sediments of the Tulear coral reef complexes (S.W. of Madagascar). Proc. 5th int. Coral Reef Congr., Tahiti 3: 377-382

Vaugelas, J. V. de (1982). Organic matter composition in lagoon sediments of French Polynesia. Proc. 4th int. Coral Reef Symp., Manila 2: 411-416

Yentsch, C. S., Menzel, D. W (1963). A method for the determination of phytoplankton chlorophyll and phaeophytin by fluorescence. Deep Sea Res. 10: 221-231

Manuscript first received: February 7, 1990

Revised version accepted: January 3, 1991 